\section{Communicating information packages in institutional face-to-face consultations} 202I, Vol. 23(I) 3-27 (C) The Author(s) 2020 (c) (i)

Article reuse guidelines: sagepub.com/journals-permissions DOI: I0.1 I77/|46|445620942907 journals.sagepub.com/home/dis

(S)AGE

\section{Marloes Herijgers and Tessa van Charldorp}

Utrecht University, The Netherlands

\begin{abstract}
Drawing on Dutch mortgage orientation consultations, the present study uncovers how mortgage advisors communicate information packages to laypersons. These information packages are jointly constructed by advisors and customers as a distinct activity within a professional advisory setting. We name this activity 'explicative telling'. Through a systematic analysis of 57 of such explicative tellings we will demonstrate that this explicative telling activity consists of $(I)$ doing preliminary work; (2) a body in which (a) general, official information about a specific mortgage topic is given and (b) information is applied to the customer's situation; and (3) (pre-)closing sequences. Essential to the explicative telling activity is the recipient orientation of mortgage information, and also the advisors' display of accountability for providing eligible information. This is supported by the irreversibility of the preliminary phase and by the presence of news deliverer upshot formulations during the body of the telling.
\end{abstract}

\title{
Keywords
}

Conversation analysis, expert-lay interaction, explicative telling, information packages, institutional interaction, mortgage consultations

\section{Introduction}

Mortgages are complex products. It is therefore not surprising that during mortgage consultations vast knowledge asymmetries occur, leading to numerous moments of 'information providing' by institutional agents. In order to prepare customers for a well-balanced mortgage purchase decision, mortgage advisors deliver 'extended spans of single speaker

\footnotetext{
Corresponding author:

Tessa van Charldorp, UiL-OTS, Utrecht University, Trans 10, 35 I2 JK, Utrecht, The Netherlands.

Email: t.c.vancharldorp@uu.nl
} 
talk' (Ford, 2004), containing generic information on mortgage related matters. While the longer turns at talk are delivered 'live' during the consultation sessions, they sound as if they are pre-recorded and replayed in each consultation session. It is for this reason that they caught our attention.

In this article we will refer to these longer turns as delivering information packages (IPs), since they are recognizable as informative discourse units (Houtkoop and Mazeland, 1985) that are jointly created by participants. Advisors project the delivery of IPs as extended turns from the beginning - displaying they want to continue their turnat-talk so far. Customers do not interrupt advisors before advisors have delivered their entire IP. Customers merely respond to the delivery of IPs with minimal tokens, such as continuers, minimal acknowledgments and surprise tokens. In other words, customers show to be dedicated recipients that allow advisors to retain the conversational floor. Consequently, we wanted to explore the first question: how do advisors and customers jointly construct the delivery of IPs?

Exploring the delivery of IPs in Dutch mortgage consultations, we noticed that participants orient to three phases: a preliminary phase, mid-telling phase (the body) and (pre-)closing phase (which has also been observed in earlier work on institutional talk by Lammers, 2006). We call the activity by which mortgage advisor deliver IPs: explicative telling (see 'Explicative telling' section for an elaborate account). In line with other telling activities such as the telling of a joke (Sacks, 1974), a story (Jefferson, 1978) and telling troubles (Jefferson, 1988) explicative tellings are produced by one person, but jointly constructed in interaction with response tokens. This led us to our second question: How are explicative tellings sequentially organized?

Our third research question was triggered by the fact that Dutch mortgage advisors are obliged by law to provide clear and transparent information (WFT, Art. 4:19), while the Dutch national oral examination regulation (CDFD, 2016) requires advisors to adjust mortgage information to customer's level of understanding (Hypothecaire financiering, 2a.2; 2a.3). Hence, we are also interested in: how are information packages adjusted to customers' pre-existing knowledge and how do they correspond with customers' level of understanding?

In what follows, we will start by introducing the activity of explicative telling and relate it to other activities that have been studied within CA to show its similarities and differences. Subsequently, we will present our data and provide more details on the Dutch mortgage purchase process. Then we will demonstrate the sequential organization of an explicative telling, focusing on the preliminary phase, the body and (pre-)closing sequences. We will argue that the practices used in the three phases contribute to the activity as a specific type of activity. We will show that once an explicandum, that is, something that requires explication, is introduced by an advisor, the activity of the IP delivery is practically irreversible. Finally, all answers to our research questions contribute to our argument that explicative tellings are deployed by the advisor to serve their professional accountability.

\section{Explicative telling}

Mortgage advisors aim at closing knowledge gaps. Due to the Dutch legislation mentioned in the introduction, mortgage advisors are prohibited to provide advice during the orientation 
consultation. They ultimately attempt to sell their mortgage products but in the mean time they serve their customers by offering mortgage information with regard to mortgage procedures, mortgage concepts and mortgage options. As such information is (financially) complex, these procedures, concepts and options are explained to customers. The term 'explaining' or 'offering information' does however not adequately cover the action that mortgage advisors are doing when communication information packages to customers.

We found references to 'explaining' in educational contexts, concerning mathematic teachers' activities (Koole, 2010; Koole and Elbers, 2014). Koole (2010) describes explaining interactions in mathematics classes as a particular type of interaction that can be sequentially organized in different ways. The overall goal here is always teaching and learning, just like Waring et al. (2013) who discuss the activity of explaining in ESLclassroom settings where again the goal is teaching. 'Explaining' has also been linked to other activity types: accounting for behaviour or explaining motivations (i.e. Antaki, 1988, 1994). However, these types of explanations have the power to redefine what is going on (Antaki, 1988), whereas in our data, the information packages are not meant as accounting for another action of the speaker.

The online Cambridge dictionary defines 'to explain' as 'to make something clear or easy to understand by describing or giving information about it'. Explaining, describing and giving information therefore, seem to be closely related definition wise. It is no surprise therefore that in conversation analytic literature, the explaining activity relates to other explanatory activities, of which information-giving (see: Heritage and Sefi, 1992; Kinnell and Maynard, 1996; Silverman, 1997; Silverman et al., 1992), is the most closely related. Like explaining, information-giving is the business of presenting information in a 'factual or non-normative framework' lacking any normative additions such as 'If I were you, I would . . .' (Heritage and Sefi, 1992). According to Silverman et al. (1992), during information giving the 'message' is nonspecific and non-personalized and thus not applied to the recipient's situation (i.e. this medication can cause nausea). When information is delivered recipients align by showing a 'wait and see' attitude; they generally produce minimal response tokens and unmarked acknowledgements and the deliverers get to do all the talking. In the Dutch mortgage setting we do see that the information is adapted to the customer's situation and recipients do more than 'wait and see'.

Interestingly, the body of literature that focuses on information-giving is conceptualized in contexts in which advice-giving, frequently unsolicited, is the institutional agents' core business (e.g. health visitors: Heritage and Sefi, 1992; HIV-counsellors: Kinnell and Maynard, 1996; Silverman et al., 1992). In those particular contexts advice-giving is often found to be problematic (Kinnell and Maynard, 1996) due to moral dimensions linked to the institutional context in which advice is provided. In these contexts information-giving is established as an alternative activity for advice-giving; sometimes the information delivery format even functions as a 'cover up' for advice-giving (Silverman, 1997).

A similar activity that can for example be found in both education and medical counselling is instructing (Pilnick, 1999). Explaining differs from instructing because an instruction functions to enable a subsequent action. Instructing therefore also does not cover what mortgage advisors are doing as no subsequent action is required from the customers.

In other words, the activity of delivering information packages is not an explanation-, advice-, information-giving or instructing activity. Rather, it shares characteristics with 
other telling activities, because it contains the distinctive pattern of a preliminary, a midtelling and (pre-)closing phase (as will be unpacked further in section 'The sequential organization of explicative tellings'). Just like the activity of explaining, our activity's goal is also to create mutual understanding of a specific term or concept. Just like with information-giving, in our activity, information is exchanged through larger discourse units. To summarize, through the use of larger discourse units, a mortgage advisor can both explain complex terms and processes and apply this to the customer's situation to create mutual understanding. Since none of the terms discussed so far describe what the mortgage advisors are doing when communicating an information package in institutional consultations, we will introduce a new term for this activity: explicative telling. In this article, we will unpack the sequential organization and the specific practices that make this activity a distinct type of institutional activity.

\section{Data}

The data in this study are drawn from a corpus of 33 mortgage orientation consultations (MOC's) that have been audio- and video recorded at one of the largest banks in the Netherlands, from July until December 2013. The duration of these recordings varies from 45 minutes to over 2 hours and we were able to record 10 different advisors.

We started off by gathering advisors' explicative tellings in the first 10 consultations that answered the following criteria:

(1) The explicative tellings were part of a larger delivery of an IP presented as a discourse unit (Houtkoop and Mazeland, 1985). The IP is produced as a more or less coherent series of successive multi-unit turns and recipients show to confine themselves to recipiency by producing minimal receipt tokens.

(2) The explicative telling is spontaneously advisor-initiated.

These criteria left us with a sizable selection of excerpts that enabled us to pin down the most important topics in the consultations, demonstrated by the frequency by which they are explained. We chose to include the six most frequent topics in our explicative tellings collection, concerning: (1) mortgage repayment forms (i.e. annuity mortgage and linear mortgage); (2) mortgage interest rate periods; (3) mortgage conditions (budget mortgage vs house mortgage); (4) national mortgage guarantee (a Dutch trust fund); (5) personal resources, such as savings or parental gifts; and (6) legal changes as of the 1st January 2013, affecting mortgage policies. We used additional examples from the remaining 23 orientation consultations to refine our analysis. This led to a corpus of 57 explicative tellings concerning the above topics. The data in this article were transcribed using Jefferson's (2004) notation system.

\section{Additional information on orientation consultations}

A ban on commission for financial advice was launched on 1st January 2013 to increase the transparency of Dutch financial information (BGfo Wft, Art. 86C). In response to this ban, financial institutions chose to introduce a free-of-charge mortgage orientation consultation (MOC) that replaces the free-of-charge advice they offered previously. This 
$\mathrm{MOC}$ is the most frequently occurring conversation in the series of mortgage consultations that take place in the purchase process, followed by advice consultations and quote consultations that both occur at a far smaller scale.

In the free-of-charge MOC advisors spend most of their time providing information; they deliver customer mortgage information concerning the institution's rules and procedures, the customer's possible mortgage options (e.g. mortgage forms, interest rates, safeguards against certain risks) and the amount of money the institute is willing to offer (Herijgers and Pander Maat, 2017). Subsequently, customers decide whether they want to proceed with this institution to purchase a mortgage, but also whether they would like to have advice with their mortgage purchase.

One of two reasons customers require an MOC is to develop a realistic idea of the amount of money they can borrow to buy a new house. Contact with an advisor is the only way to learn this since the internet doesn't provide information as detailed as required to start the bidding process on the housing market. Consequently, the main interactional activities in the MOC are: gathering customer data, providing information and explaining things. The second reason why customers visit an advisor is because they want to know the issues that need to be decided upon when purchasing a mortgage (Herijgers and Pander Maat, 2015).

\section{The sequential organization of explicative tellings}

The focus of this article is on explicative tellings which are activities that deliver an information package as it were from advisor to customer. We position explicative tellings as a distinct activity within mortgage orientation consultations. Mazeland (2019) refers to activity as a term 'reserved for more encompassing courses of action', building upon a variety of definitions from, Levinson (1992), Heritage and Sorjonen (1994) and also Jefferson (1988) who refers to the larger activity 'troubles talk' as a discrete organizational domain. Typical for discrete organizational domains according to Mazeland is that they are jointly organized as such, set apart from surrounding or parallel activities and 'accomplished through the use of (ensembles of) practices that make actions and organizations recognizable as actions and organizations in, for, and of a specific type of activity.' (p. 29).

We will argue that an explicative telling is characterized by three phases: (1) a preliminary phase in which the explicative telling is 'launched'; (2) a body, in which the official information that is the main concern of the explicative telling is 'delivered' and applied to the customer's situation; and (3) (pre-)closing sequences, in which the explicative telling is 'landed' or closed. Once the advisor has started an explicative telling, the action is more or less irreversible; it is hardly possible for a customer to push back an explicative telling delivery. In this section, we will further unpack the practices that make explicative tellings distinct activities.

\section{Preliminary work}

The explicative tellings in our consultations start with preliminary work. By conveying uncertainty and withholding response in reaction to IP launches customers orient to advisors' expertise regarding mortgage related information (similar to what has been found in 
healthcare data, i.e. Drew, 1991; Silverman, 1987). This preliminary work is characterized by four practices that will be unpacked below: (1) seeking alignment with delivery of an IP; (2) IP delivery pre-announcement; (3) IP delivery account; and (4) package summaries.

Seeking alignment with IP delivery. The first practice that characterizes the preliminary phase is seeking alignment with the IP delivery. We know that in storytellings, the preface is crucial for the go-ahead of the story (Sacks, 1974). We also know that the preface allows story recipients to block the further telling, for example if they have already heard the story or if they require more information for the story to be understood (Sacks, 1974). If the telling receives a go-ahead, continuers such as hmn $\mathrm{mm}$, uh huh or yeah generally show alignment to the story being told; the story recipient 'aligns with the activity still in progress' (Stivers, 2008: 34). In excerpt 1, we see how the advisor invites his customer(s) to commit to participation of the pre-packaged discourse unit by seeking alignment. Excerpt 1 illustrates this as the advisor (AD) launches her IP delivery about national mortgage guarantee, which is a national trust fund that prevents customers from going bankrupt when they are faultlessly faced with indebtedness as the result of a divorce, unemployment or a deceased partner. Before this extract starts, the participants have already talked about their income, their current housing situation and what kind of price range they are currently looking at in order to buy their first home. MC is a male customer, $\mathrm{FC}$ is a female customer.

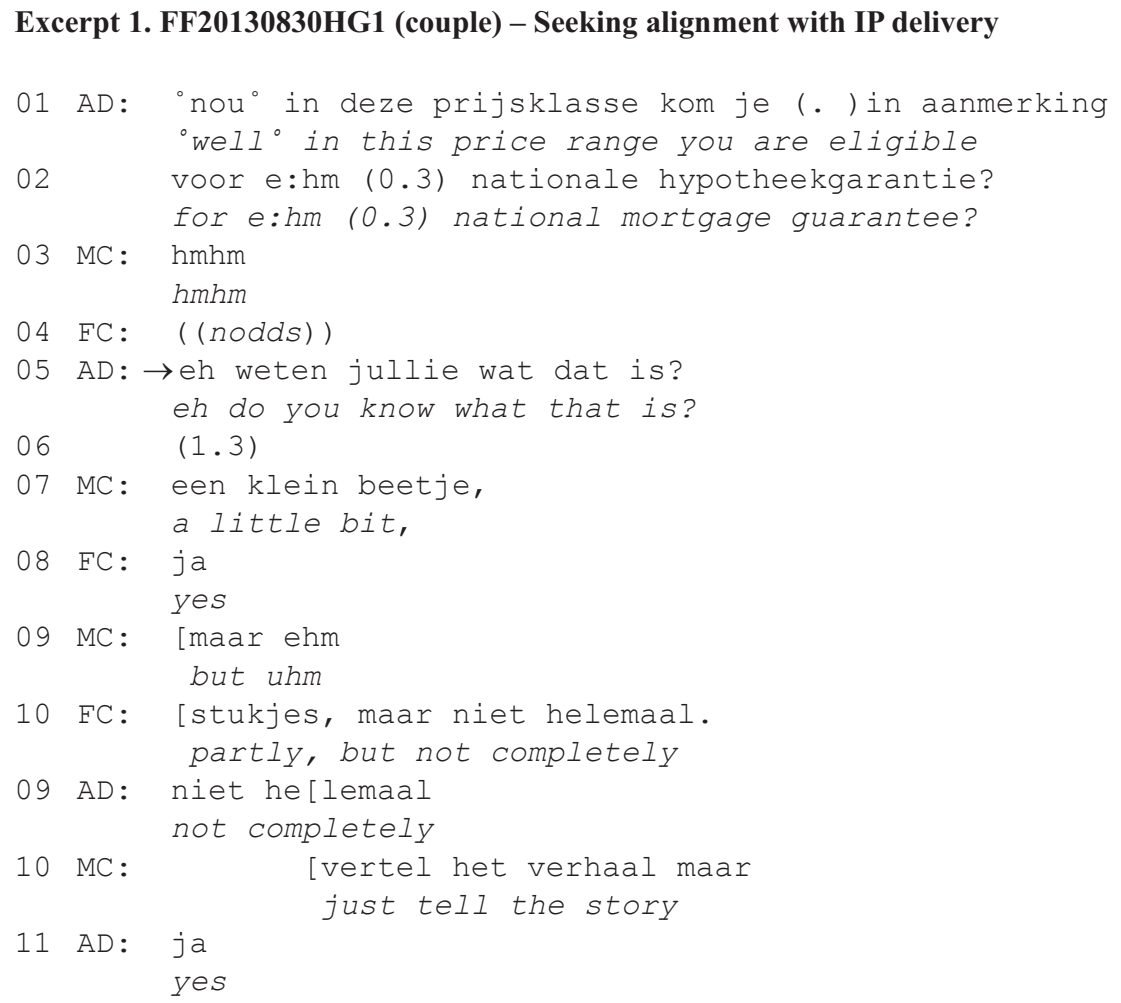




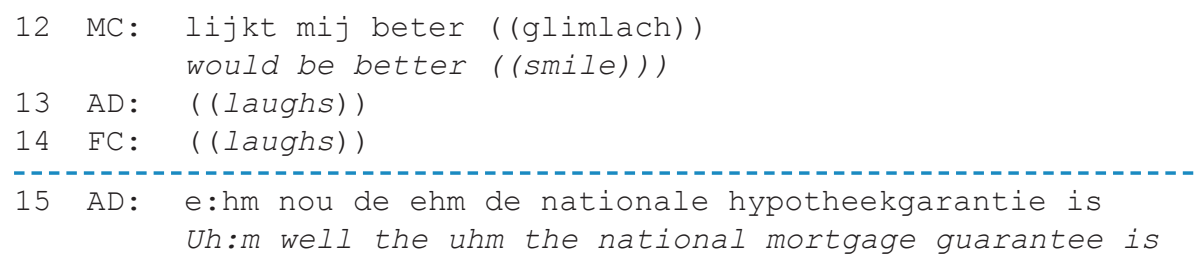

At the start of the fragment the female advisor builds upon the previously gathered information and introduces the concept of 'nationale hypotheekgarantie' (national mortgage guarantee) by announcing that her customers are eligible candidates (lines 1/2). By doing this she nominates a candidate unpackable. With the hesitation marker 'ehm' (line 2) she seeks special attention for the explicandum and marks the explicandum as delicate (see Silverman and Peräkylä, 1990), orienting to the customers' probable non-understanding of the try-marked explicandum. So far, the customers have not shown convincing familiarity with the term. In return, her customers allow her to unpack the unpackable by producing continuers (lines 3/4) that allow her to go ahead and continue. Then the advisor proceeds in line 5 by establishing alignment with the IP delivery by asking ' $d o$ you know what that is'. Her customers do not treat this question as a request for demonstrating their knowledge, which is the preferred action when someone asks a 'knowing'question (Koole, 2010). Instead, MC claims to know 'a little' (line 7) through a gloss that downplays whatever he may know about it. FC provides a 'yes' (line 8) but resists a knowledge demonstration by displaying that she knows 'parts, not completely' (line 10) by which she claims knowledge gaps. Subsequently, MC even encourages the advisor to release the IP with 'tell the whole story' (line 10) including an account that it 'would be better' (line 12) as well as a smile that might indicate some kind of shame or fear related to the lack of knowledge he displays. The advisor and FC's laughing demonstrates that they ratify MC's ludic framing of the situation (Glenn, 2003: 54) and agree on the joint activity that will take place next: the IP delivery. This shows that launching this activity is not about partial or superficial knowledge, rather, the information should be precise and more or less exhaustive. Any indication that this is not the case warrants the launching of the specific type of activity, namely an explicative telling.

In line 15 the actual IP delivery starts: the advisor claims the floor and marks the beginning of a new topic (Mazeland, 2003; Schegloff, 2010) and attracts attention for her next action with 'eh:m' (Schegloff, 2010). Her 'nou' ('well') (line 15) not only projects an extended turn (Heritage, 2015; Pander Maat et al., 1986; Schegloff and Lerner, 2009) but also announces a next step (Mazeland, 2016) and she starts her delivery by mentioning the referent (national mortgage guarantee) again at the beginning of her turn.

In sum, this excerpt demonstrates that IPs can be launched by establishing alignment combined with presenting an unpackable project. This excerpt and others in the data collection show that advisors and customers have a strong preference for pursuing the IP delivery and a launch is generally irreversible. In the rare case that a customer tries to block the onset of an IP delivery, his/her refusal is overruled by the advisor. This is not surprising, since advisors are accountable for providing correct information and can never be sure if customers truly understood what certain mortgage concepts actually mean prior to an IP delivery. 
Excerpt 2 demonstrates what happens when a male customer (MC) tries to withhold an IP delivery. The advisor (AD) seeks permission for her IP delivery on different mortgage forms: the annuity mortgage and the linear mortgage.

\section{Excerpt 2. FF20130712HG1 (customer + father) - Preference for agreeing with IP delivery}

$01 \mathrm{AD}$ : Dan komen we bij de aflosvormen, Then we get to the repayment forms,

02 we hebben eigenlijk nog maar twee vormen we actually have only two forms still over-eh sinds [één januari? left-uh since first of January?

04 MC : [( (giggles..................))

$05 \mathrm{AD}$ :

[voor eh voor nieuwe hypotheek eh eh eh klante for uh for new mortgage wh uh uh customers

06 MC:

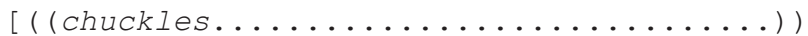

$07 \mathrm{AD}$ : en dat is de annuiteit of de (.) lineaire hypo个theek, and that is the annuity or the (.) linear mortgage, b-uh $>$ i think $<$ you k-know a little bit hoe [het in elkaar steekt about the ins and outs

10 MC: [gewoon i- annuiteit gewoon just i-annuity you know

11 AD: okeej. okaay.

12 MC: lin-air ga je (.) e:: h steeds minder betale (.8) lin-ear you (.) u:: :h pay less each time

13 dat is voor mij niet zo e:h gunstig that is for me not so u:h favorable

$14 \mathrm{AD}$ : ja- e-zal ik 'm as 'm kort even? yes-u-shall I it if it just briefly

15 ((continuing motion with arms))

$16 \quad(0.7)$ nog [uitleggen (0.7) still explain

$17 \mathrm{MC}: \quad[j a$ als je 't graag wil, yes if you really want to,

18 ((moves body out for disengagement by leaning back))

$19 \mathrm{AD}: \quad \mathrm{ja} \uparrow$ yes $\uparrow$

$20 \mathrm{MC}: \quad$ (

$21 \mathrm{AD}$ : ehm bij een lineaire hypotheek word (.)je (.) uhm with a lineair mortgage you will (.)

Like in excerpt 1 , the advisor starts her explicative telling by seeking attention for the new topic that requires explication (line 1). She introduces this topic as if working through a checklist: 'then we get to. . '. Subsequently, she provides a package summary concerning 
a new legislation since 1st January due to which the mortgage repayment forms have changed. Her customer starts to chuckle in response to her general gloss, by which he indicates he knows the story behind these recent changes. His chuckling triggers the advisor to respond with a declarative question with a very flat epistemic gradient, but high on the $\mathrm{K}+$ scale (Heritage and Raymond, 2012), displaying she assumes that he knows the ins and outs of mortgage repayment forms (lines 8/9) and that he believes an explanation is not necessary. The explicandum is not as strongly try-marked as in excerpt 1, but we see a slightly rising pitch at the end of line 7 , isolating the unpackable. MC demonstrates that he has already decided for a specific repayment type and assesses this in terms of his personal situation (line 10,12,13). The advisor continues with another attempt to seek alignment with her IP delivery in line 14, making the act of delivery very small ('just briefly'). Her customer initially withholds an uptake (line 16) and then when the advisor produces an expansion, he finally responds in slight overlap agreeing with the IP delivery ('if you really want to') formatted as a favour to $\mathrm{AD}$. By doing this, the customer treats the explicative telling as something that should be done, but at the same time showing he is not very much interested as we can also conclude from his physical behaviour (lines 18/19) and his sighing (line 20). The advisor begins her IP delivery in line 21.

In sum, there are various practices to establish recipient alignment with the delivery of an IP. Advisors make clear that the explicandum is not about partial, fragmentary or superficial knowledge, but it is information that should be precise and more or less exhaustive. Every indication that this is not the case, warrants and triggers an IP delivery. The pattern we see is that $\mathrm{AD}$ mentions a candidate unpackable, marking it with rising intonation or pitch and together with recipient response(s), the participants jointly produce a warrant of its unpacking. Through this they establish a normative framework for the delivery of a specific type of activity: an explicative telling. That the trajectory is irreversible even when a customer attempts to withhold an IP delivery shows an orientation to this precise and exhaustive explanation.

IP delivery pre-announcement. The second practice that characterizes the preliminary phase is the pre-announcement of an explicative telling and proceeding with the IP delivery immediately after the pre-announcement. A pre-announcement projects and generally negotiates its delivery - it projects a next-next action contingent on the acceptance of the offer to tell the announcement (Teresaki, 2004: 182). In excerpt 3 below, this acceptance by the customer is minimal - however, the advisor immediately proceeds with the telling. In this explicative telling, the advisor talks to his customers (only FC is hearable in this excerpt) about the costs that will occur during the mortgage purchase process. He lists the various costs while looking at the customers and then produces an explicative telling about the last item he mentioned, the 'national mortgage guarantee'. He uses a stand-alone pre-announcement to introduce the IP.

Excerpt 3. FF20130801HG1 (couple) - Pre-announcement and immediately proceeding

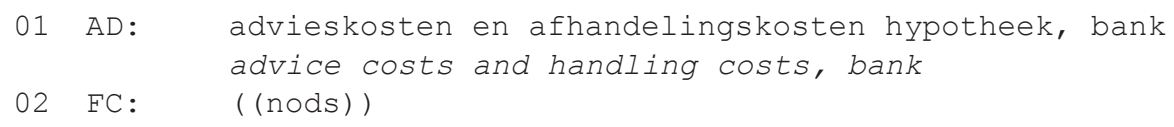




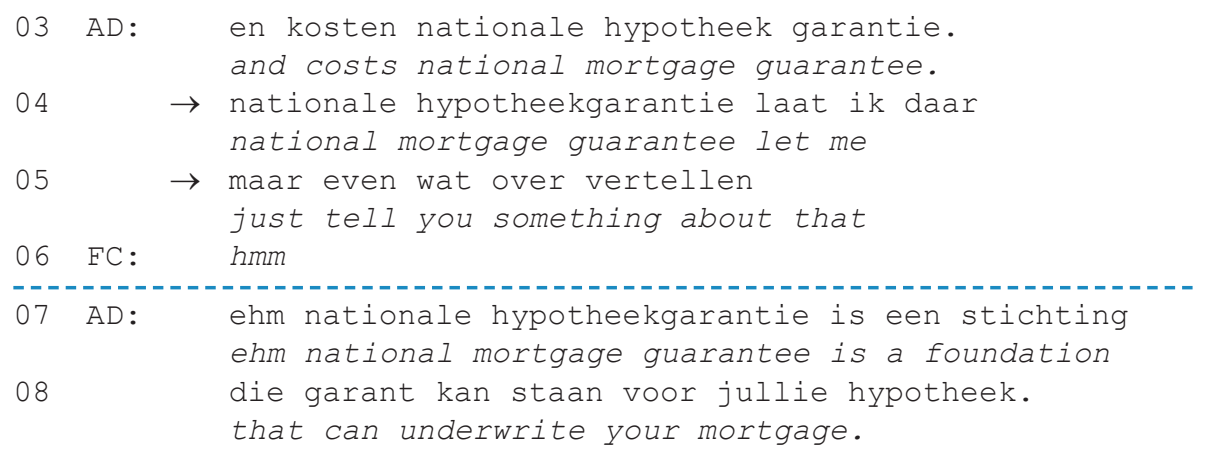

The pre-announcement of the IP delivery in this excerpt is provided in lines 4-5 and includes a pre-positioned topic introduction (Mazeland, 1992), "national mortgage guarantee'. With this pre-announcement the advisor launches the IP and the customer accepts AD's offer to tell with a continuer ' $\mathrm{hmm}$ ' (line 6), giving space to the advisor to deliver his IP. The delivery follows immediately, starting with an 'ehm' claiming the floor followed by a definition of the explicandum.

IP delivery account. The third practice that is used by advisors to launch the IP in the preliminary phase is an account for the explicative tellings: a self-explication of why they deliver the IP. This account does not seem to occur as frequent as the other practices we have identified and can be found in combination with pre-announcements of IP deliveries, but also on its own functioning as a preface. Excerpt 4 illustrates how the advisor (AD) provides an account for his explicative telling prior to the onset of the IP delivery, in order to make the IP relevant to his customer.

\section{Excerpt 4. FF20130919HG1 (1 customer) - Accounting for IP delivery}

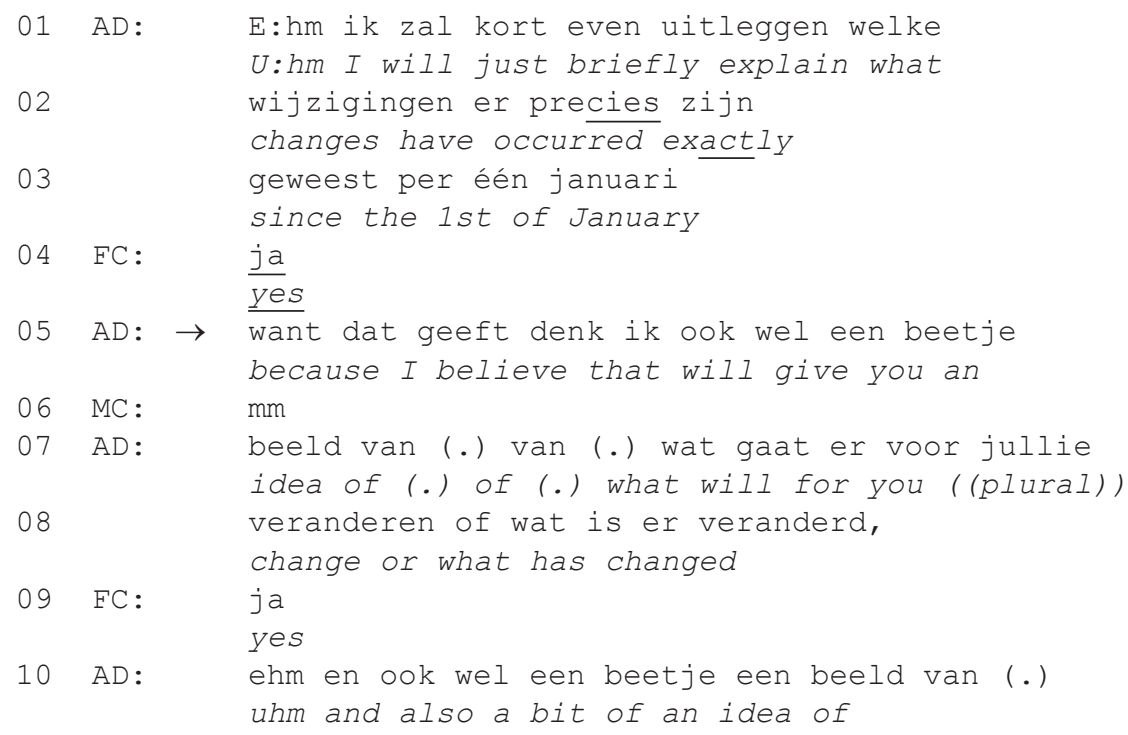




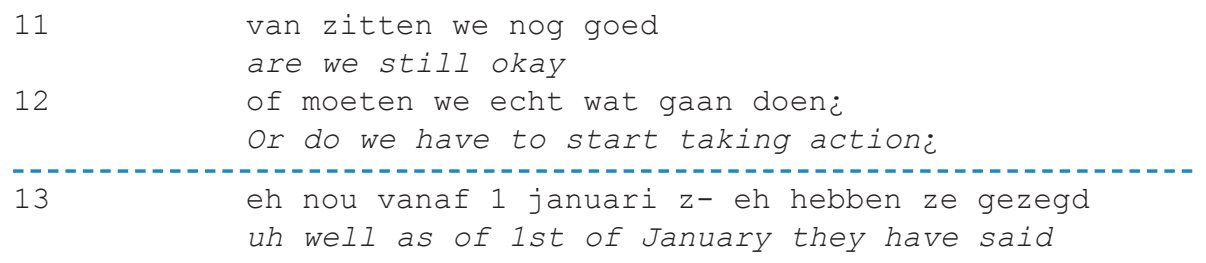

In this excerpt, the account-sequence (5-12) follows the pre-announcement sequence (1-4) in which the advisor announces that he will briefly explain the changes that have occurred since January, which is acknowledged and approved by his customer with the Dutch 'ja' (Jefferson, 1984; line 4). Subsequently, the advisor provides an account for his IP, making it relevant to his customer (lines 5-8). The IP will clarify what changes have occurred and will occur in their personal situation. By making the IP relevant the advisor marks the importance of the IP delivery. The customer acknowledges this again (line 9) leaving the floor open for the advisor to continue. The account here is therefore used as a practice for casting the projected telling as a specific type of activity. The IP to be delivered will have an update function ('what changes have ocurred') and a check function ('are we still okay' or 'on the same page'). Both functions increase the advisor's epistemic authority on the matters to be discussed.

Package summaries. The last practice that is used to introduce the explicandum and launch the IP is the package summary. This package summary is usually accompanied with a verbal (e.g. 'listen') or physical token (e.g. pointing at it) to draw attention to the new topic and projects elaboration. In our collection we see that once the advisor has verbally or physically pointed to the new explicandum, they fire away without any pre-announcement. We also see that the more elaborate these summaries are, the more they already deliver the kernel of information to be provided. For this reason, they can also become part of the body of the explicative telling. Whereas they can arguably belong to both phases, we have chosen to include package summaries here as part of the preliminary phase of the explicative telling as the actual content of the explicandum is never fully unpacked in the package summary. Extract 5 demonstrates such a package summary.

\section{Excerpt 5. FF20130718HG1 (couple) - package summary}

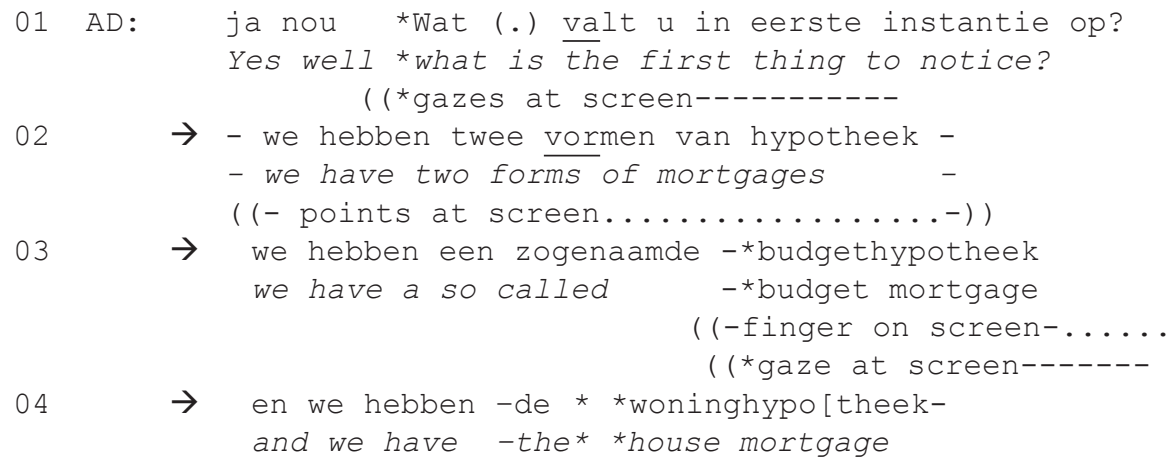




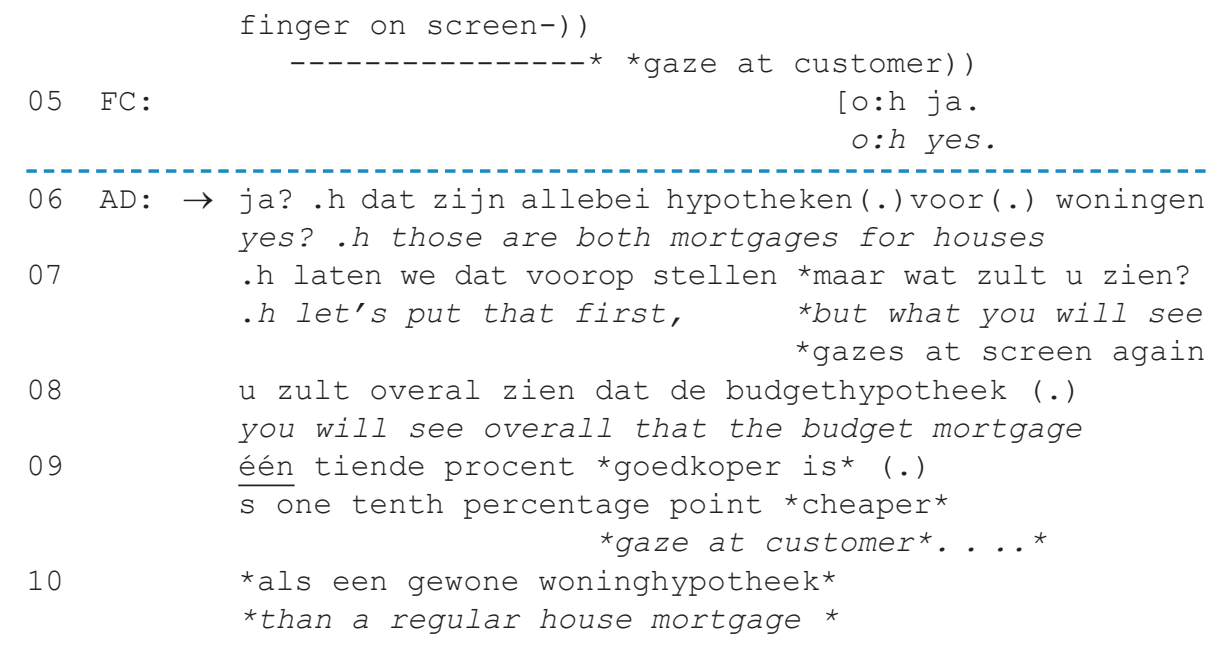

The advisor attracts attention to the explicandum by producing a package summary and pointing at his computer screen (lines 2-4) to show that there are two different mortgage forms. He points at the two different forms individually, while mentioning the budget mortgage (line 3 ) and the house mortgage (line 4). His introduction of the mortgage forms is acknowledged with a news receipt and recognition claim ' $o: h$ yes' in line 5. Subsequently, in line 6 the advisor begins with the presentation of the information package.

These characteristics of 'package summaries' resonate the characteristics of topic summaries ('topicsamenvattingen' in Mazeland, 2003: 188), which is Mazeland's translation of the phenomenon 'news announcement' (Button and Casey, 1985). However, IP summaries require 'unpacking' and are treated as such by both the deliverer (i.e. the advisor) and the recipient (i.e. the customer), whereas topic summaries/news announcements are not always unpacked. Moreover, both Mazeland (2003) and Button and Casey (1985) illustrate their phenomenon with examples from spontaneous natural interaction and there the topic summaries/news announcements examples always report an activity that happened in the past, whereas 'package summaries' can also report on current state of affairs (for instance: 'we have two different mortgage forms').

To summarize, we have demonstrated four practices that can occur during the IP launch: (i) seeking alignment with IP delivery; (ii) IP delivery pre-announcement; (iii) IP delivery account; and (iv) package summaries. As we have seen, these practices can be used on their own, or in combination. By using one or more of these four preliminary phase practices, customers are not only prepared for what is to come, but advisors are also 'doing being a professional': through these practices, they demonstrate that they are in the $\mathrm{K}+$, they can choose and initiate explicandums, account for them, deliver them and provide package summaries of what is to come. Even if a customer attempts to withhold a launch during the preliminary phase, the AD continues the launch. Furthermore, advisors are accountable for providing relevant, correct and intelligible information. This is the role they also present during the introduction stage of the orientation consultation; they are there to help customers understand the mortgage process as well as the terms 
and concepts involved in that process. In the next paragraph we will demonstrate how advisors start off with the IP delivery and how they hold the floor while delivering the IP.

\section{Delivering information packages: The body ${ }^{1}$}

Once the advisor has launched the IP and the customers have aligned with the upcoming IP delivery, both advisors and customers agree on jointly constructing the full IP as a discourse unit. Excerpt 6 demonstrates how the advisor (AD) makes use of his obtained right to deliver the IP and be the primary speaker for the total IP delivery. It also shows how the male customer (MC) commits himself to recipiency in order to enable the advisor's activity.

In order to demonstrate how advisor and customer jointly enable the IP delivery, we will point out several practices advisors use to retain the conversational floor and we will point out how delivering IP's accomplish the activity of explicative telling. We will show how the advisor displays that his turn is not final yet, but can also display that his turn has come to an end, allowing the customer to take a next turn. At the same time we will shed light on the practices by which the customer withholds from interrupting the advisor during his IP delivery and how upshot formulations draw out the implications of the generic IP for the customer's individual situation. All these practices can be found in excerpt 6 .

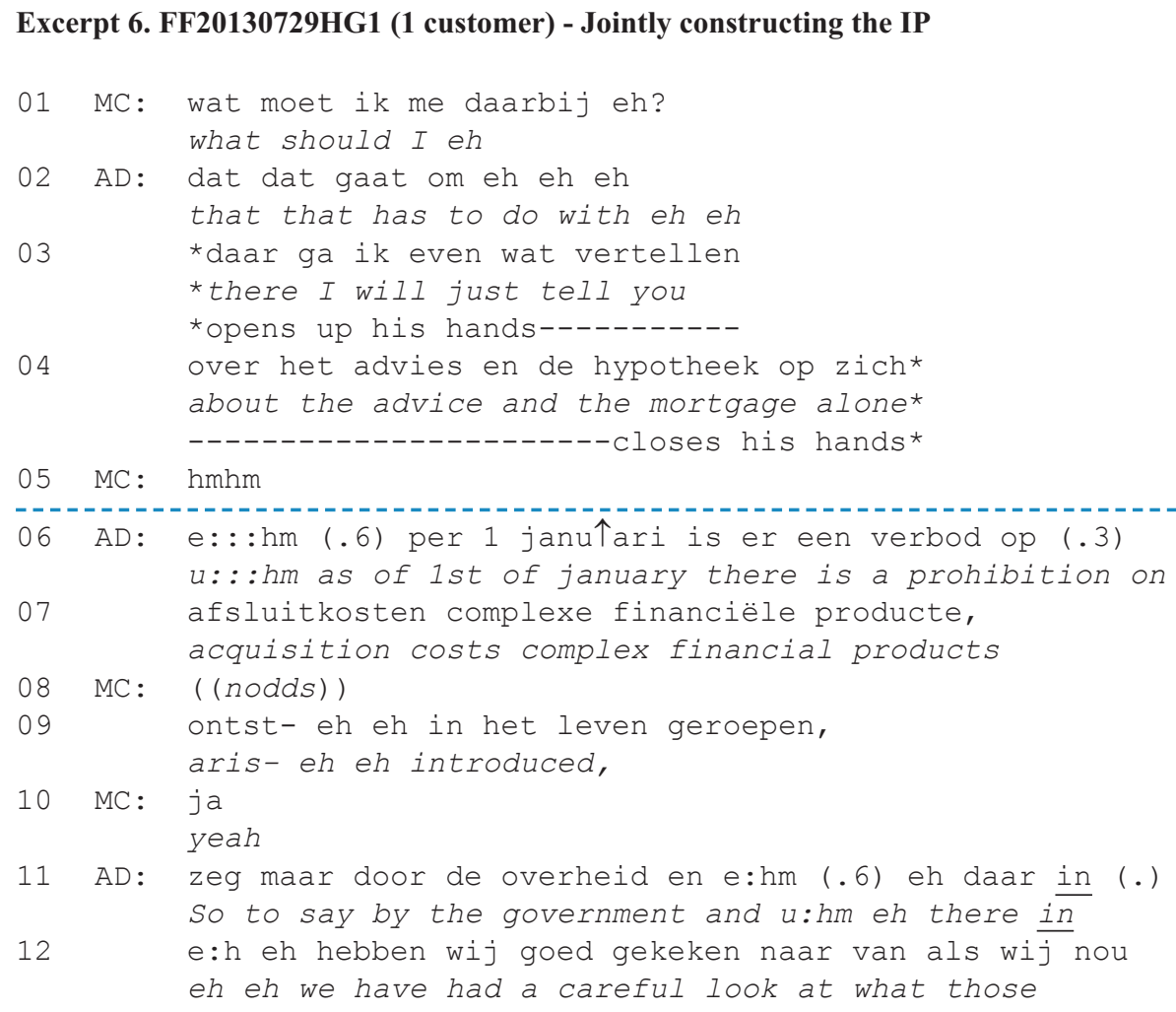


$22 \mathrm{AD}$ : en wij niet alleen, alle banken and not just us, all of the banks

$23 \mathrm{MC}: \quad(($ nodds $))$

$24 \mathrm{AD}$ : hebben dat op zo'n manier gedaan, have done that in such a way

25 en je betalt dus (.) voor (.) een stukje advies, and so you pay for a piece of advice

$26 \mathrm{MC}: \quad($ (nodds $))$

$27 \mathrm{AD}$ : om jouw persoonlijke situatie in kaart te brengen, to map out your personal situation

$28 \mathrm{MC}:(($ nodds $))$

$29 \mathrm{AD}$ : ongeveer zoiets als wat we nu aan het [doen zijn a bit like what we are doing right now

30 MC :

$31 \mathrm{AD}$ : maar dan (.3)

but then

$32 \mathrm{MC}:($ (nodds) $)$

$33 \mathrm{AD}$ : veel uitgebreider, much more elaborate

$34 \mathrm{MC}: \quad(($ nodds $))$

$35 \mathrm{AD}$ : *met overlijdensrisicodekkingen*

*with term life insurance*

( (*counting one on fingers*))

36 MC: ((nodds))

$37 \mathrm{AD}$ : *en arbeidsongeschiktheid*

*and labor disability*

( (* counting two on fingers*))

$38 \mathrm{AD}$ : *en noem maar op allemaal*, [.hh

*and you name it all*

((*counting three on fingers*))

$39 \mathrm{MC1}: \mathrm{ja}$

yeah

$40 \mathrm{AD}$ : als je wat ouder bent met pensioenregelingen, When you are a little older with pension arrangements

$41 \mathrm{MC}: \quad(($ nodds $))$

$42 \mathrm{AD}$ : en eh het hele thet hele gebeuren, [.hh

And eh the complete $w^{-}$a the complete situation

*gazes down $>>>>>>>>>>>>>>>>>>>$

43 MC :

[hmhm

$44 \mathrm{AD}$ : en e: $:$ h eh daarnaast betaal je*

And e: $:$ h eh next to that you pay

$>>>>>>>>>>>>$ gazes down*

( ( 8 LINES OMITTED ))

51 eh eh eh een percentage, uh uh uh a percentage

52 MC: oké okay

$53 \mathrm{AD}$ : in plaats van een vast *bedrag. instead of a fixed price

*gazes down $>>>>>>>>>>>$ 


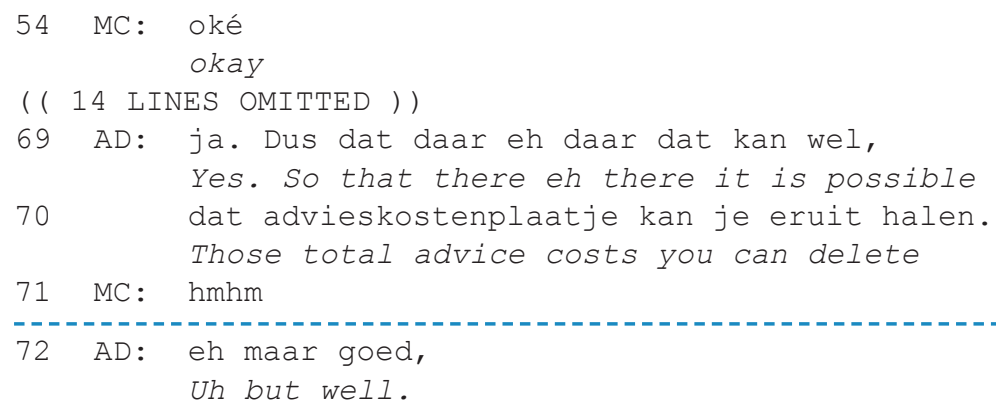

The explicative telling in excerpt 6 is launched by the advisor with a pre-announcement (line 3) accompanied by a topic nomination on what the IP will be about, namely the advice and the mortgage itself (line 4). Firstly, this pre-announcement displays the advisor is about to produce an extended turn. Secondly, the topic nomination displays that the advisor is about to launch an information package, since these complex topics require unpacking in these consultations. Both of these practices invite the customer to commit to recipiency, thus allowing the advisor to deliver his full IP. The customer in return agrees with the IP delivery and his role as passive recipient (Jefferson, 1984), displaying a minimal continuer ' $\mathrm{hmhm}$ ' (line 5).

The advisor starts his IP delivery with an extended 'uhm' (line 6) claiming the conversational floor and produces a turn that is syntactically and pragmatically complete, but prosodically projects there is more to come by not using a turn-final intonation. This practice of avoiding turn-final intonation, to prevent signalling a transition relevant place as complete, also occurs in line 9, 24, 25, 29, 31. Another practice to hold the conversational floor is visible in line 11, where the advisor produces an 'and $u: h m$ ' as a kind of 'rush-through' technique (Schegloff, 1982: 76) to signal there is more to come without projecting anything about its form or content. This turn-keeping practice is also used in line 44 . Another advisor practice that shows to be effective to reclaim the floor is by taking inbreaths at possible TRPs, which we can see in line 38 and 42.

While all these practices above have to do with verbal and audible practices, there are also visible practices, such as gaze behaviour and gestures. For reasons of space, we cannot analyze and report on all the visible practices that occur in our data. However, examples include gaze behaviour midway through the IP delivery (lines 40-42); the advisor gazes down at his paper work, by which he avoids eye contact with his customer during two TRPs. Gestures by the advisor also indicate that a turn has not come to a completion yet. For instance in lines $33,35,36$ the advisor counts on his fingers to emphasize and project that he is constructing a list that has to do with the topics that will be discussed whenever the customer chooses to enter an advice consultation. The advisor is not only successful in holding the floor but the minimal response tokens are also indicative of the participation framework that advisor and customer create: the advisor is doing the explicative telling and the customer is doing receiving information. Throughout the entire IP delivery, MC only nods (lines 8, 23, 26, 28, 30, 32, 34, 36, 41) or responds with 'yeah' (lines 10,39), 'hmhm' (line 5, 43, 71) or 'okay' (lines 52, 54). 


\section{Upshot formulations}

In extract 6, the delivery ends with an upshot self-formulation (Garfinkel and Sacks, 1970; Heritage and Watson, 1980). Upshot self-formulations are the most frequently occurring practice used in the body phase of explicative tellings. This is no surprise since we already know that upshot formulations, often prefaced by 'so', are known to display the completion of complex turns (Raymond, 2004). Advisors routinely use these upshots to summarize the IP's gist and - more importantly - translate the generic information to the customer's situation. These upshot self-formulations are used to draw out the implications of the generic IP for the customer's future situation, while referring to customer's actions to take.

In excerpt 6 the advisor delivers an upshot-formulation in lines 69 to 70, in which he refers to his customer's freedom to take out a mortgage without advice and thus delete the advice costs. With his formulation he reflects upon the customers' mortgage costs with regard to the action to not proceed with an advice consultation.

There are numerous institutional settings in which upshot formulations are produced by news recipients (Antaki et al., 2005; Kevoe-Feldman, 2015) who feel responsible for their own understanding of information. This is not the case with explicative tellings in this institutional setting. Advisors take responsibility for giving eligible and comprehensible information using news deliverer formulations. By doing this, advisors show they are accountable for making customers understand the implications of the explicandum. At the same time, such upshot self-formulations make the customer less responsible for their true understanding of information. Customers are in no way invited to actively demonstrate their understanding.

These practices illustrate that both advisor and customers participate in the same activity of delivering an information package and they show their understanding of this activity to each other by completing the IP in a coordinated way. Through a variety of holding-the-floor techniques, unpacking the explicandum, translating generic information to the customer's situation, and using upshot self-formulations, advisors demonstrate a further accountability for providing precise and exhaustive explanations. Both advisor and customer orient to the advisor as the $\mathrm{K}+$ information provider and the customer as (passive) recipient.

\section{(Pre-)closing sequences}

The landing of the information package is the final phase of the explicative telling. Unlike other forms of tellings, such as a story-telling or joke-telling there are no recognizable punchlines (Sacks, 1974), nor is there a list of completion markers (Jefferson, 1990) that indicate the telling is completed. So, to show their customer(s) that the explicative telling is coming and has come to an end the advisors make use of pre-closing sequences and closing sequences.

Excerpt 7 demonstrates the landing of an IP in which the advisor has just explained what personal resources a customer can bring when he wants to apply for a mortgage. This excerpt illustrates two practices that we have identified from our explicative tellings collection. Unlike what this may suggest, these landing practices do not always occur in combi- 
nation with each other, advisors also use them separately. The (pre-)closing practices we identified are: (1) using formulaic expressions to solicit understanding (Drew \& Holt, 1988, 1998); and (2) references to the IP launch by which the advisors 'return to base'. This extract concerns an explicative telling concerning investing savings and extra value from a previous home.

\section{Excerpt 7. FF20130712HG1 customer + father) - Closing sequence explicative telling}

01 AD: oké ja wat wat ik altijd belangrijk vind is okay yes what what I always find important to

02 om mee te geven van stop niet al je spaargeld erin let you know is not to put all your savings into it

03 ehm gaat de wasmachine kapot, gaat de auto kapot uhm if the washing machine breaks down, the car breaks down

04 dan moet je natuurlijk wel eh then you need to have eh

$05 \mathrm{MC}$ : precies exactly

06 AD: een buffer hebben om dat op te kunnen vangen a buffer to take care of that

( ( 5 LINES OMITTED ) )

$21 \mathrm{AD}$ : eh maar heb je bijvoorbeeld dertigduizend eh but if you have for instance thirty thousand

22 euro overwaarde uit je oude woning dan zegt de fiscus euro extra value from your old house then the taxman says

23 als je dat meefinanciert op je nieuwe woning, if you finance that on your new house

24 dan heb je over die dertigduizend euro geen renteaftrek. you will not get tax deduction over that thirty thousand.

$25 \mathrm{MC}:($ (nodds))

26 AD: ehm dus je moet er rekening mee houden dat Ehm so you have to take into account that

27 alles wat je in de woning stopt dat je dat everything you put into a house that you will

28 eigenlijk nooit meer terugkrijgt. actually never get it back

29 je krijgt het terug in stenen, een dak boven je hoofd you will get it in bricks, a roof over your head

$30 \mathrm{MC}:$ [ja precies yes exactly

31 AD: [het is niet weg it is not gone

$32 \mathrm{MC}:$ nee no

33 AD: ehm maar het is niet meer vrij opneembaar. uhm but you cannot take it out freely anymore

$34 \mathrm{MC}$ : nee precies no exactly 


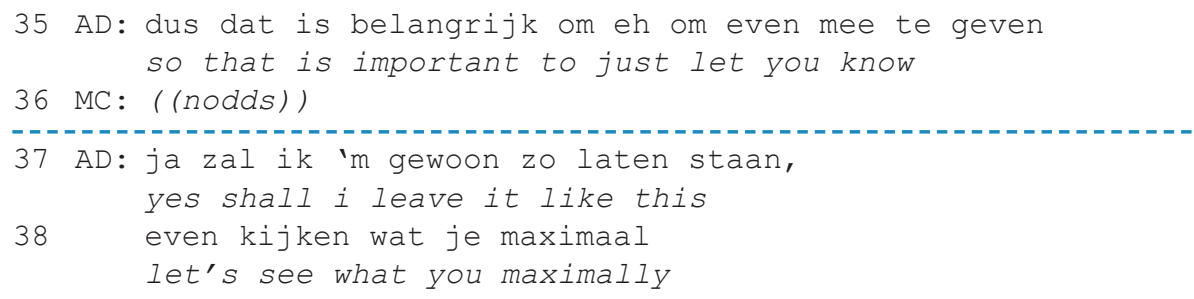

In excerpt 7 the advisor announces her IP delivery providing the kernel of the message (lines 1/2). Then she delivers her IP in lines 3 to 24, providing two reasons not to use all your savings. The first reason is given in lines 3 to 6 where the advisor explains that one ought to have some savings in case of unexpected costs. The second reason is given in lines 7 to 24, partly omitted for reasons of length, where she explains that you need to invest any additional value after selling your house, into a new house. In order to explain the legislation to her customer, she uses a reported speech format in line 22: 'the taxman says' and voices the rules as how they are provided by the Dutch tax authorities. Her reported speech ends in a transition relevant place, since her utterance is syntactically, pragmatically and prosodically complete (Ford and Thompson, 1996). However, her customer has not claimed the floor and allows the $\mathrm{AD}$ to continue by only nodding (line 25 ) in response. As we often see, the customer is not asked to demonstrate understanding of the explicandum nor does he volunteer it. Merely nodding is sufficient for the AD to provide her own formulation and she continues in one breath into the (pre-)closing phase where she delivers a soupshot self-formulation (discussed in the previous section) starting in line 26 . We mark this the pre-closing phase (lines 26-36) because the explicandum has been unpacked and summarized. What $\mathrm{AD}$ does beyond line 28 is repetition, but in idiomatic terms, using the expression 'a roof over your head' (line 29). With this upshotformulation (Heritage and Watson, 1980) as well as this idiomatic expression (Drew and Holt, 1988) which is in itself also an additional upshot formulation, she displays that the IP is coming to an end. The customer in return responds to it with a 'yes, exactly' (line 30) by which he claims understanding, displays he has understood that the IP is completed, and agrees with moving to a close. The advisor additionally offers another formulation that is even shorter and more simplified (lines 31 and 33), but also highlights another way of looking at the same thing. By offering various, simplified idiomatic versions of the same conclusion or summary, AD solicits 'showing understanding'. This second formulation gets a repeated claim of understanding 'no' (line 32) and 'no exactly' (line 34), a much stronger acknowledgement than for example a head nod. Finally, the advisor repeats what she already said during the IP launch, that the gist of the IP is important to let him know (line 35), providing a repeated account for her IP delivery and 'returning to base'. Then in line 37 she moves on to her next topic of entering the data in her computer to find out the customer's maximum mortgage loan amount.

In excerpt 7 we illustrated the two practices that make up the (pre-)closing sequences: (1) formulaic expressions; and (2) returning to base. These practices are further elaborated on below. 


\section{Formulaic expressions}

We already know that generally idiomatic expressions and figurative expressions are used to bring topics to a closure (Drew and Holt, 1988, 1998). In our consultations advisors also use fixed expressions such as 'maar dat is koffiedik kijken', which is a Dutch expression for: 'reading the tea-leaves in the bottom of the cup' or 'in je achterhoofd houden', which translates as: 'to keep in mind'. These formulaic fixed expressions occur only during IP pre-closings and are upshots or part of upshot formulations that summarize the preceding talk to initiate topic closing. Excerpt 8 is another illustration of this phenomenon, because it shows explicitly that not only advisors, but also customers treat formulaic expressions as topic closing devices.

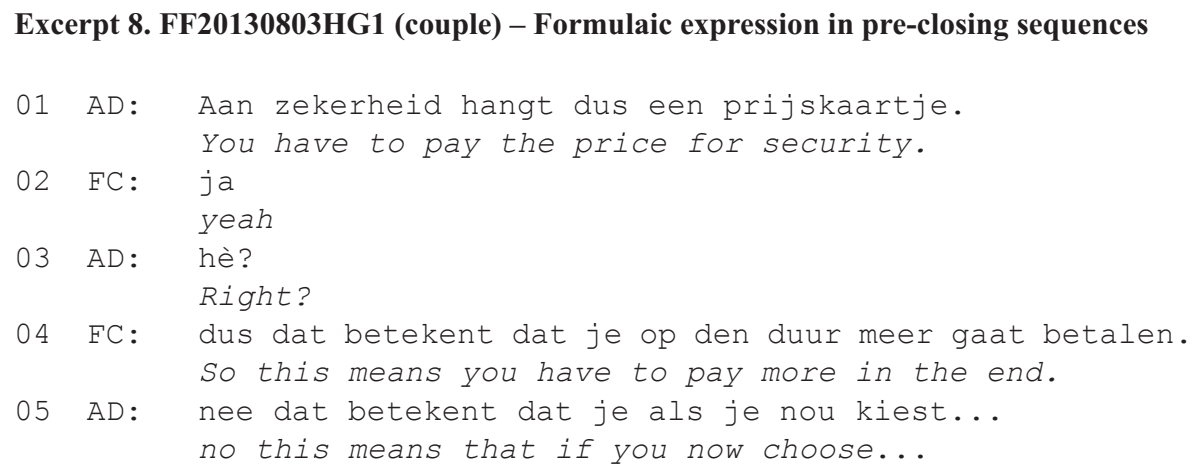

The advisor (AD) lands his IP in line 1 with a formulaic expression about the price you have to pay for something, in this case security. The customer (FC) responds to this with a minimal token ' $y e a h$ ', which is not sufficient for the advisor to close the topic, given that the advisor continues to mobilize a sufficient response by producing a tag question (line 3; Stivers and Rossano, 2010). The tag question is treated by the customer as a request for agreement with topic closure, since she responds with a so-upshot declarative formulation: 'So this means you have to pay more in the end' that conveys her understanding of the IP. This upshot formulation displays that she agrees with topic closure in the first place, since formulations are closing implicative (Schegloff, 2007), but it also shows why she didn't provide a closing implicative response to the advisor's idiomatic expression in the first place; she was not sure if she understood the advisor correctly. Line 4 shows that her doubt was legitimate as she poses an understanding question. This re-opens the application stage of the explicandum and AD initiates a new explicative telling in line 5 in order to repair his customer's understanding of the IP: 'no this means that if you choose. . .

With this excerpt and other examples in our data (not shown) we argue that formulaic expressions that occur during IP landings are considered to be explicative telling closing devices by advisors as well as customers, particularly when accompanied by connectives such as 'so', etc. However, unlike upshot formulations, they are - in this sequential context - not linked to prospective actions, and therefore are part of the closing sequence of the activity. 


\section{Return-to-base device}

The final re-occurring practice to close the explicative telling, is the 'reference to the IP launch', such as we already saw in excerpt 7 , line 35 . When advisors refer to the IP launch they repeat words, phrases or the gist of an utterance that they also used during the IP launch. This re-addressing of the opening of a telling is a common practice to close tellings in natural interaction (See Mazeland, 1992: 355, 2019: 37; Schegloff, 2007: 186, 2011). In the specific situation of explicative tellings the mortgage advisors can refer to several launch practices. Sometimes, they refer to the account that they already presented during the preliminary phase of the activity, such as we saw in excerpt 7. In line 1 the advisor tells her customer that there is something she wants to let him know, because it is important: 'what I always find important to let you know'. During the closing sequences she repeats this account in the exact same words (line 35). At other times the advisors refer to the package summary that they displayed during the preliminary phase, such as: 'I have two sorts of mortgages' and refer to the principal idea of this package summary in the closing sequence again 'just know there are two possibilities'. Although the advisor does not use the exact same wording, the gist of the summary is the same.

\section{Conclusion and discussion}

The aim of this article was to explore the extended turns of talk by which mortgage advisors deliver mortgage information to prospective home buyers. We have shown that in certain extended stretches of talk advisors deliver information packages (IPs) that provide generic information concerning customer possibilities, legislation or institutional policies. Mortgage orientation consultations are unexplored from a conversation analytic perspective and hence there is no term for the activity we frequently noticed when advisors are delivering information packages to customers. The delivery of these IPs shows similarities with people telling stories or jokes. However, we also identified practices that are only found when IPs are delivered. Thus, we argued that IP delivery should be considered a distinct conversational activity type that we propose to call 'explicative telling'.

We illustrated that explicative tellings are presented in three phases. First, they contain a preliminary phase, second, a mid-telling ('the body') and finally, the (pre-)closing sequences. We showed that preliminaries and mid-telling sequences are important activities when it comes to IPs, because they are used by advisors to translate the generic IP to a customer's situation, which also makes explicative tellings distinct from information giving.

The preliminary work during which IPs are launched has two main characteristics. First, launches are almost irreversible. Second, launches can contain four different practices: (1) advisors seek customer alignment with an IP delivery; (2) advisors account for an IP delivery; (3) advisors announce an IP delivery; and (4) advisors present a package summary that needs unpacking.

The IP delivery is recognized by the active incipient advisor and the supportive recipient customer. Together, customer and advisor jointly construct the IP; the advisor produces generic information and the customer allows the advisor to continue by not 
interrupting. In order to translate the IP's generic information into something that is relevant to the customers' situation, the advisor initiates upshot formulations, including so-upshots. Formulations in which news deliverers summarize their own previous talk have not received any conversation analytical attention before. Ever since the distinction was made between news deliverer formulations and news recipient formulations (Heritage and Watson, 1979) attention went out to news recipient formulations in institutional settings. Prior research concluded that recipient formulations translate laypersons accounts into institutional relevancies (Drew, 2003). However, in our data this translation is the other way around; institutional information is translated to customer relevancies. During the (pre-)closing sequences, references can be made to the IP launch, which is a common practice when closing other forms of tellings too. Furthermore, formulaic expressions are used to close the explicative telling.

So far, we have focused on the delivery of the discourse unit on the level of turn-taking and the sequential organization of explicative tellings. We carefully discussed the term we used for the phenomenon. However, a more prominent question may be: for what problem is this a solution? Why do advisors use explicative tellings? Our best guess would be that the advisor is always the official authority and that he has to act accordingly, which results in a rather monologic consultation. In the rare case of an expert prospective mortgage customer in our data, it seems that the amount of explicative tellings is lower and the conversation is more dialogic than with unexperienced customers. Expert customers are active recipients who ask questions when the advisor provides information. These differences are worth exploring in the future. Additionally, it may be interesting to compare explicative tellings with information-providing activities in other institutional settings such as doctor-patient or judge-suspect interaction, as they will serve different institutional purposes.

Through the use of explicative tellings advisors aim to explain mortgage related terms and procedures to customers. Advisors never know exactly what prior knowledge customers possess and it would cost them a lot of time to find out. Therefore, it is more efficient to estimate the customers' level of knowledge and provide a sensible and comprehensible explicative telling, designed in accordance with the advisor's best practices as the result of long-term information-providing experience. By presenting an explicative telling, advisors reduce the risk that customers miss out or fail to understand important information. This point is supported by one of the advisors who remarks: 'I'll probably tell you some things that you already know, but that is just to make the story more sensible.' In other words, it is better to be safe than sorry. Furthermore, the data also shows that customers feel that it is better to be safe than sorry; when asked what customers already know about certain mortgage related terms, they often respond with a small demonstration of their knowledge and add up that they would like to hear what the advisor has to say about it. Besides, explicative tellings will generally not be closed without a customer's token of understanding. As the analyses show, advisors put a lot of effort in marking the importance of the IP delivery through the use of launches and landings. At the same time, customers are never invited to demonstrate understanding, as one expects teachers do when explaining important information in class. Whether or not customers really understand the explicative telling remains unknown. 
On the basis of the analyses presented here, we would like to suggest that explicative tellings are a practice for 'doing being professional'. In other words, advisors display accountability for providing eligible and comprehensible information through the preliminary work, the body and (pre-)closing information packages. At the same time customers easily let mortgage advisors 'be the professional', explicitly and literally putting themselves comfortably in the layperson's chair.

\section{Acknowledgements}

We would like to thank Tom Koole and Henk Pander Maat for their comments and suggestions to preliminary versions of this article and the anonymous reviewer for the detailed and helpful comments. We would also like to thank the mortgage advisors and mortgage customers' allowing us to record their consultations.

\section{Declaration of conflicting interests}

The author declared no potential conflicts of interest with respect to the research, authorship and/ or publication of this article.

\section{Funding}

The author(s) disclosed receipt of the following financial support for the research, authorship, and/ or publication of this article: This work was financially supported by the Netherlands Organisation for Scientific Research (NWO) and ABN AMRO in the Comprehensible Language and Effective Communication programme. The views and opinions expressed in this article are the sole responsibility of the authors.

\section{Note}

1. This paragraph is not as elaborate as the ones devoted to the preliminary phase and the (pre-) closing sequences. Whereas less is known about preliminary phases and closing sequences, the co-construction of larger discourse units has been studied before (see Ford, 2004; Houtkoop and Mazeland, 1985; Selting, 2000). Although there is a lot more to say about delivering information packages, for reasons of space, we have kept this section brief.

\section{References}

Antaki C (ed.) (1988) Analysing Everyday Explanation. London: Sage.

Antaki C (1994) Explaining and Arguing. The Social Organization of Accounts. London: Sage.

Antaki C, Barnes R and Leudar I (2005) Diagnostic formulations in psychotherapy. Discourse Studies 7(6): 627-647.

Button G and Casey N (1985) Topic nomination and topic pursuit. Human Studies 8(1): 3-55.

CDFD (2016) College Deskundigheid Financiële Dienstverlening. Eindtermen en toetsmodule $2 \mathrm{a} .2$ \& 2a.3. http://www.cdfd.nl/examen/toetstermen/hypothecair-krediet (accessed 7 July 2016).

Drew P (1991) Asymmetries of knowledge in conversational interactions. In: Markova LI and Foppa K (eds) Assymetries in Dialogue. Hemel Hempstead: Harvest Wheatsheaf, pp. 21-48.

Drew P (2003) Comparative analysis of talk-in-interaction in different institutional settings. In Glenn P, LeBaron C and Mandelbaum J (eds) Studies in Language and Social Interaction. Mahwah, NJ: Lawrence Erl- baum Associates, pp. 293-308. 
Drew P and Holt E (1988) Complainable matters: The use of idiomatic expressions in making complaints. Social Problems 35(4): 398-417.

Drew P and Holt E (1998) Figures of speech: Figurative expressions and the management of topic transition in conversation. Language in Society 27(4): 495-522.

Ford CE (2004) Contingency and units in interaction. Discourse Studies 6(1): 27-52.

Ford CE and Thompson S (1996) Interactional units in conversation: Syntactic, intonational, and pragmatic resources for the management of turns. In: Ochs E, Schegloff EA and Thompson S (eds) Interaction and Grammar. Cambridge: Cambridge University Press, pp. 134-184.

Garfinkel H and Sacks H (1970) On formal structures of practical actions. In: McKinney JC and Tiryakian EA (eds) Theoretical Sociology. New York: Appleton-Century-Crofts, pp. 337-366.

Glenn P (2003) Laughter in Interaction, vol. 18. Cambridge: Cambridge University Press.

Herijgers MLC and Pander Maat HLW (2015) How to evaluate multichannel communication packages: A case study on mortgage information. International Journal of Bank Marketing 33(6): 857-878.

Herijgers MLC and Pander Maat HLW (2017) Navigating contextual constraints in discourse: Design explications in institutional talk. Discourse Studies 19(3): 272-290.

Heritage J (2015) Well-prefaced turns in English conversation: A conversation analytic perspective. Journal of Pragmatics 88: 88-104.

Heritage J and Sefi S (1992) Dilemmas of advice: Aspects of the delivery and reception of advice in interactions between health visitors and first time mothers. In: Drew P and Heritage J (eds) Talk at Work. Cambridge: Cambridge University Press, pp. 359-419.

Heritage J and Sorjonen ML (1994) Constituting and maintaining activities across sequences: And-prefacing as a feature of question design. Language in Society 23(1): 1-29.

Heritage J and Watson DR (1979) Formulations as conversational objects. In: Psathas G (ed.) Everyday Language: Studies in Ethnomethodology. New York: Irvington, pp. 123-162.

Heritage J and Watson DR (1980) Aspects of the properties of formulations in natural conversations: Some instances analysed. Semiotica 30(3-4): 245-262.

Heritage J and Raymond G (2012) Navigating epistemic landscapes: Acquiescence, agency and resistance in responses to polar questions. In: de Ruiter JP (ed.) Questions: Formal, Functional and Interactional Perspectives. Cambridge: Cambridge University Press, pp. 179-192.

Houtkoop H and Mazeland H (1985) Turns and discourse units in everyday conversation. Journal of Pragmatics 9: 595-619.

Jefferson G (1978) Sequential aspects of storytelling in conversation. In: Schenkein J (ed) Studies in the Organization of Conversational Interaction. New York: Academic Press, pp. 219-248.

Jefferson G (1984) Notes on a systematic deployment of the acknowledgement tokens 'yeah' and 'mmhm'. Papers in Linguistics 17(2): 197-216.

Jefferson $G$ (1988) On the sequential organization of troubles-talk in ordinary conversation. Social Problems 35(4): 418-441.

Jefferson G (1990) List construction as a task and resource. In: Psathas G (ed.) Interaction Competence. Washington, DC: University Press of America, pp. 63-92.

Jefferson G (2004) Glossary of transcript symbols with an introduction. In Lerner GH (ed.) Conversation Analysis: Studies from the First Generation. Amsterdam: John Benjamins, pp. 13-31.

Kevoe-Feldman H (2015) Closing the gap in customer service encounters: Customers' use of upshot formulations to manage service responses. Pragmatics and Society 6(1): 67-88.

Kinnell AMK and Maynard DW (1996) The delivery and receipt of safer sex advice in pretest counseling sessions for HIV and AIDS. Journal of Contemporary Ethnography 24(4): 405-437.

Koole T (2010) Displays of epistemic access: Student responses to teacher explanations. Research on Language and Social Interaction 43(2): 183-209. 
Koole T and Elbers E (2014) Responsiveness in teacher explanations: A conversation analytical perspective on scaffolding. Linguistics and Education 26: 57-69.

Lammers H (2006) Explicatie afsluitende 'ja?'-sequenties in gesprekken tussen medewerkers en cliënten van de sociale dienst. Vijfde sociolinguistische conferentie. In: Koole T, Nortier J and Tahitu B (eds) Papers Vijfde Sociolinguistische conferentie. Delft: Eburon, pp. 342-353.

Levinson S (1992) Activity types and language. In: Drew P and Heritage J (eds) Talk At Work. Cambridge: Cambridge university press, pp. 66-100.

Mazeland H (1992) Vraag/antwoord-sequenties. Amsterdam: Stichting Neerlandistiek VU.

Mazeland H (2003) Inleiding in de Conversatie Analyse (Introduction to Conversation Analysis). Bussum: Uitgeverij Coutinho.

Mazeland H (2016) The positionally sensitive workings of the Dutch particle nou. In: Auer P and Maschler Y (eds) NU/NA: A Family of Discourse Markers Across the Language of Europe and Beyond. Berlin: Walter de Gruyter, pp. 377-408.

Mazeland H (2019) Activities as discrete organizational domains. In: Reber E and Gerhardt C (eds) Embodied Activities in Face-to-Face and Mediated Settings: Social Encounters in Time and Space. London: Palgrave MacMillan, pp. 29-61.

Pander Maat H, Driessen C and van Mierlo H (1986) NOU: Functie, contexten, vorm en betekenis. Interdisciplinair Tijdschrift voor Taal- \& Tekstwetenschap 6(2): 179-194.

Raymond G (2004) Prompting action: The stand-alone 'so' in ordinary conversation. Research on Language and Social Interaction 37(2): 185-218.

Pilnick A (1999) 'Patient counseling' by pharmacists: Advice, information or instruction? The Sociological Quarterly 40(4): 613-622.

Sacks H (1974) An analysis of the course of a joke's telling in conversation. In: Bauman R and Sherzer J (eds) Explorations in the Ethnography of Speaking. Cambridge: Cambridge University Press, pp. 337-353.

Schegloff EA (1982) Discourse as an interactional achievement: Some uses of 'uh huh' and other things that come between sentences. In: Tannen D (ed.) Analyzing Discourse: Text and Talk. Washington, DC: Georgetown University Press, pp. 71-93.

Schegloff EA (2007) Sequence Organization in Interaction: Volume 1: A Primer in Conversation Analysis, vol. 1. Cambridge: Cambridge University Press.

Schegloff EA (2010) Some other 'Uh(m)'s. Discourse Processes 47(2): 130-174.

Schegloff EA (2011) Word repeats as unit ends. Discourse Studies 13(3): 367-380.

Schegloff EA and Lerner GH (2009) Beginning to respond: Well-prefaced responses to wh-questions. Research on Language and Social Interaction 42(2): 91-115.

Selting M (2000) The construction of units in conversational talk. Language in Society 29(04): $477-517$.

Silverman D (1987) Communication and Medical Practice. London: SAGE.

Silverman D (1997) Discourses of Counselling: HIV Counselling as Social Interaction. London: SAGE.

Silverman D, Perakyla A and Bor R (1992) Discussing safer sex in HIV counselling: Assessing three communication formats. AIDS Care 4(1): 69-82.

Silverman D and Peräkylä A (1990) AIDS counselling: The interactional organisation of talk about 'delicate' issues. Sociology of health and illness, 12(3): 293-318.

Stivers T (2008) Stance, alignment and affiliation during storytelling: When nodding is a token of affiliation. Research on Language and Social Interaction 41(1): 31-57.

Stivers T and Rossano F (2010) Mobilizing response. Research on Language and Social Interaction 43(1): 3-31.

Teresaki AK (2004) Pre-announcement sequences in conversation. In: Lerner GH (ed.) Conversation Analysis: Studies From the First Generation. Amsterdam: John Benjamins, pp. 171-223. 
Waring HZ, Creider SC and Box CD (2013) Explaining vocabulary in the second language classroom: A conversation analytic account. Learning, Culture and Social Interaction 2: 249-264.

\section{Author biographies}

Marloes Herijgers received her $\mathrm{PhD}$ within the Utrecht Institute of Linguistics OTS. Her thesis focuses on customer-centeredness with regard to the design of mortgage information in general and mortgage consultations specifically.

Tessa van Charldorp is Assistant Professor Communication and Information Sciences in the Language and Communication group within the Utrecht Institute of Linguistics OTS. Her research focuses on institutional interaction. 